\title{
19. 動学的応用一般均衡モデルによる自動車交通外部不経済削減政策の国民経済的評価
}

The Economic Evaluation of Policies for the Regulation of Automobile-related External Diseconomies with the Dynamic Computable General Equilibrium Model

武藤慎一*・上田孝行 $* * \cdot$ 笹尾和樹 $* * * \cdot$ 森杉壽芳 $* * * *$

Shinichi MUTO, Takayuki UEDA, Kazuki SASAO, Hisayoshi MORISUGI

\begin{abstract}
Recently, issues of external diseconomies caused by automobiles have been a world-wide great concern. The diffusion policy of clean energy vehicle is expected to reduce the volume of automobile among some policy options. We try to evaluate the diffusion policy of clean energy vehicle with the dynamic computable general equilibrium model. In this model, the learning effects of manufacturing clean energy vehicle industry and the measurement of externality regulatory benefits by diffusing clean energy vehicles are considered. In case studies, we cleared that the diffusion policy is effective for decreasing externalities, and the twice social net benefit is generated by providing the subsidy.
\end{abstract}

KEYWORDS; external diseconomy, regulatory policy evaluation, dynamic computable general equilibrium model

\section{1. 背景·目的}

近年，自動車交通に起因する大気污染や騒音， $\mathrm{CO}_{2}$ 排 出による地球温暖化といったいわゆる外部不経済の問 題が深刻化している ${ }^{1)}$. これに対し, 自動車関連税の増 徵策のような経済政策の実施が検討されるとともに, 最近の自動車産業の技術開発に伴い，低公害車の製造・ 販売が本格的に実現しつつある状況を受けて，低公害 車の普及を通して環境負荷の低减を図ろうという動き が見られる2).

しかし，低公害車の製造には，研究開発費や製造設 備改善費等の新たな費用が発生するため，低公害車の 価格は従来の高公害車の価格よりかなり高くなってし まい，それが低公害車の普及の障害となっていること が指摘されている. そこで, 本研究では, 筆者らがこ れまで自動車関連税垃徵策の評価のために用いてきた 動学的応用一般均衡 (Dynamic Computable General Equilibrium: DCGE)モデル ${ }^{3)}$ の拡張を行うことにより， 低公害車の普及予測とともに, 普及促進政策として補 助金政策を実施することによる効果について分析を行 うことを目的とする.

* 岐阜大学 Gifu University

** 東京工業大学 Tokyo Institute of Technology

*** 飛島建設 Tobishima Corporation

**** 東北大学 Tohoku University

\section{2. 動学的応用一般均衡モデルの搆策}

本動学的応用一般モデルは, 静学モデルを一期とし, 毎期ごとに市場が清算される枠組みを想定しており， 基本的には筆者らの構筑した DCGE モデル ${ }^{3)}$ と同様で ある. ただし, 本モデルでは, 低公害車製造産業の行 動モデルの精緻化を行っている，すなわち，低公害車 製造産業の習熟効果 4を, 累積生産量の増加とともに費 用が低减する外部効果と捉え, 各経済主体の行動モデ ルは規模に関して収穫一定の技術を仮定するが，動的 には規模の経済が衝く構造のが定式化されている.

ここではまず，モデルの仮定を示した後，各経済主 体, 特に低公害車製造産業の行動モデルを説明し, 資 本ストックおよび自動車保有台数の蓄積について解説 を行うこととする.

\section{1 モデルの仮定}

本モデルは，以下の仮定に基づいている.

1)社会は, 産業(低公害車製造産業を含む), 運輸産業, 集計された 1 家計，中央政府からなるものとする. そ の相互関係は，図 1 に示すとおりである.

2)産業は, 労㗢, 燃料種類別自動車資本(低公害車を含 む), 非自動車資本からなる生産要素および中間投入 財を投入して生産活動を行う。ただし，自動車資本は 
自動車運輸産業によってのみ投入される.

3)家計は, 生産要素を提供することにより所得を得て, その所得をもとに産業で生産された財・サービスを消 費する.

4)旅客運輸サービスに関し, 産業が生産に投入する旅客 運輸サービスは，実際には自家生産しているものであ っても全て旅客運輸産業によって提供されているもの とする. また，家計が消費する旅客運輸サービスは， 基本的に旅客運輸産業によって提供されるとするが, 自家用自動車に関わる旅客運輸サービスは，家計自ら が生産して自らが消費するものとする.

5)市場は, 各生産物の財市場と, 労㗢, 燃料種類別自動 車資本および非自動車資本からなる生産要素市場が存 在する.

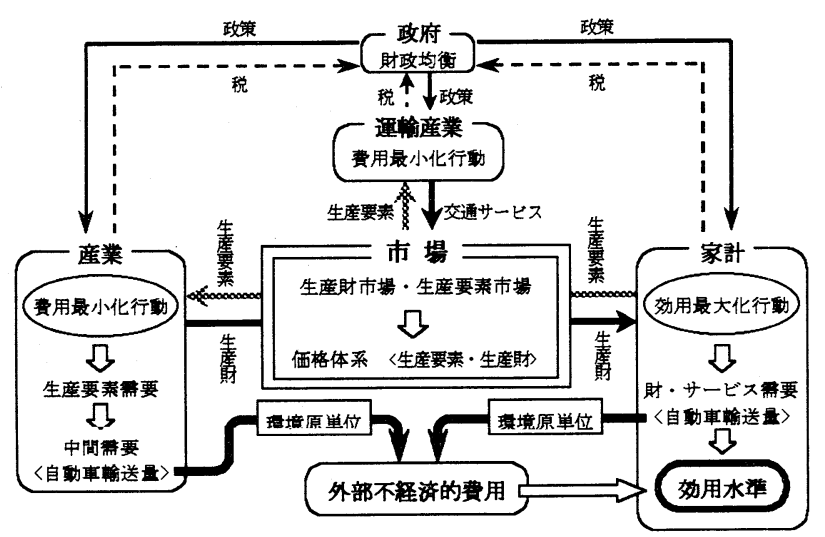

図 1 各経斉主体の相互関係

\section{2 産羓(除低公害車製造産羓)の行動モテル}

産業は，生産要素および中間投入財を投入して財・ サービスの生産を行う. その行動モデルは, 以下のよ うな二段階最適化行動により定式化される.

\section{(A) 財の生産行動}

まず，産業 $j$ は，生産要素をひとまとまりとみなし た合成生産要素投入量(生産容量と呼ぶ) と中間投入財投 入量を決定する. その行動モデルを, Leontief 型生産技 術制約の下での生産費用最小化行動により定式化する.

$$
\begin{aligned}
& C_{j}=\min _{x_{j}^{i}, P C_{j}} c_{j}\left(p_{L}, p_{M}, p_{K}\right) P C_{j}+\sum_{i} p_{i} x_{j}^{i} \\
& \text { s.t. } y_{j}=\min \left[\frac{P C_{j}\left(L_{j}, M_{j}, K_{j}\right)}{a_{j}^{0}}, \frac{x_{j}^{i}}{a_{j}^{i}}\right]
\end{aligned}
$$

ただし, $y_{j}$ : 産出量, $L_{j}$ : 労働投入量, $M_{j}$ : 燃料種 類別自動車資本 $M_{j}^{h}$ によって表される自動車資本投入 量, $h$ : 自動車資本の燃料種別, $K_{j}$ : 非自動車資本投
入量, $x_{j}^{i}$ : 産業 $i$ から産業 $j$ へ投入される中間投入量, $c_{j}$ : 合成生産要素の単位費用(次段階(2.2(b))にて決定), $p_{L}, p_{M}, p_{K}$ : 生産要素価格, $P C_{j}$ : 生産容量関数, $a_{j}^{i}(i \neq 0)$ : 投入係数, $a_{j}^{0}:$ 一単位の生産に必要な生産 容量を示す生産容量比率, $C_{j}$ : 費用関数.

なお，自動車資本は運輸産業のみが投入するとされ ているため, 運輸産業以外の産業については, $M_{j}=0$ と考えればよい.

式(1)を解くと, 生産容量 $P C_{j}$ と中間投入量 $x_{j}^{i}$ ととも に, 生産費用関数 $C_{j}$ が求められる.

\section{（B）生産要素投入行動}

続いて, 産業 $j$ は各生産要素の投入量を決定する. その行動モデルは, 生産容量に関わる技術制約の下で の生産要素費用最小化行動により定式化する.

$$
\begin{aligned}
& c_{j}=\min _{t_{j}, \alpha_{j}, K_{j}} p_{L} L_{j}+p_{M} M_{j}+p_{K} K_{j} \\
& \text { s.t. } P C_{j}\left(L_{j}, M_{j}, K_{j}\right)=1
\end{aligned}
$$

これを解くと, 単位生産容量あたりの各産業の生産要 素需要 $D_{L_{j}}, D_{M_{j}}, D_{K_{j}}$, および合成生産要素の単位費用 $c_{j}$ が求められる.

\section{（C）自動車資本の燃料種別選択行動}

自動車運輸産業については, 式(2)を解いて得られる 自動車資本に対し, 燃料種類別投入割合を決める必要 がある. その選択行動は, 以下のように定式化される.

$$
\begin{aligned}
& S^{F}=\max _{\mathrm{P}_{h}^{F}} \sum_{h} \mathrm{P}_{h}^{F}\left(-p_{M^{h}}\right)-\frac{1}{\theta^{F}} \sum_{h} \mathrm{P}_{h}^{F} \ln \mathrm{P}_{h}^{F} \\
& \text { s.t. } \sum_{h} \mathrm{P}_{h}^{F}=1
\end{aligned}
$$

ただし， $h$ : 自動車資本の燃料種別(低公害車を含む)を 表す, $S^{F}$ : 最大期待効用, $\mathrm{P}_{h}^{F}$ : 自動車資本投入割合, $p_{M^{h}}$ : 燃料種別 $h$ の自動車資本価格, $\theta^{F}:$ ロジットパ ラメータ.

式(3)を解くと, 燃料種別 $h$ の自動車資本選択確率 $\mathrm{P}_{h}^{F}$ が Logit Model の形にて得られる.

$$
\mathrm{P}_{h}^{F}=\frac{\exp \left(-\theta^{F} p_{M^{h}}\right)}{\sum_{h} \exp \left(-\theta^{F} p_{M^{h}}\right)}
$$

またこのとき, 最大期待効用 $S^{F}$ おひび自動車資本価 格 $p_{M}$ も得られる.

$$
\begin{aligned}
& S^{F}=\frac{1}{\theta^{F}} \ln \sum_{h} \exp \left(\theta^{F} v_{h}^{F}\right) \\
& p_{M}=\sum_{h} p_{M^{h}} \cdot \exp \left\{\theta^{F}\left(v_{h}^{F}-S^{F}\right)\right\}
\end{aligned}
$$




\section{3 生産財価格の導出}

財 $j$ の生産財価格は, 産業 $j$ の利潤最大化の条件か ら求められる.

$$
\begin{array}{ll}
\Pi_{j}=\max _{y_{j}} p_{j} y_{j}-C_{j} \\
\text { s.t. } C_{j}=\left[a_{j}^{0} c_{j}+\sum_{i} a_{j}^{i} p_{i}\right] y_{j} \\
c_{j}=p_{L} D_{L_{j}}+p_{M} D_{M_{j}}+p_{K} D_{K_{j}}
\end{array}
$$

式(6.b)(6.c)は，式(1)および式(2)を解くことにより得ら れる. そして，この最適化問題の一階条件より，

$$
p_{j}=a_{j}^{0}\left\{p_{L} D_{L_{j}}+p_{M} D_{M_{j}}+p_{K} D_{K_{j}}\right\}+\sum_{i} a_{j}^{i} p_{i}
$$

のように，生産財価格が得られる.また，この条件よ り，産業 $j$ の長期利潤がゼロであることがわかる.

\section{4 低公害車製造産業の行動モデル}

続いて，低公害車製造産業の行動モデルの定式化を 行う. 基本的な行動は, 2.3 節で定式化された産業の行 動モデルと同様である.ただし，生産費用には前期ま での累積生産量 $Y_{C}^{t-1}$ に依存して低减する単位生産量あ たりの固定費用 $F C^{t}$ を追加する.

$$
\begin{aligned}
& C_{C}{ }^{t}=\min _{P C_{C}{ }^{t}, x_{C}^{i t}} c_{C}{ }^{t} P C_{C}{ }^{t}+\sum_{i} p_{i}^{t} x_{C}^{i^{t}}+F C^{t}\left(Y_{C}{ }^{t-1}\right) y_{C}{ }^{t} \\
& \text { s.t. } y_{C}{ }^{t}=\min \left[\frac{P C_{C}{ }^{t}\left(L_{C}{ }^{t}, K_{C}{ }^{t}\right)}{a_{C}^{0}}, \frac{x_{C}^{i^{t}}}{a_{C}^{i}}\right]
\end{aligned}
$$

この最適化問題の解は, 2.1.で求められた通常の産業 における最適解と同様になる. ただし, 費用関数 $C_{C}{ }^{t}$ は，以下のようになる.

$$
C_{C}{ }^{t}=\left[a_{C}^{0} c_{C}{ }^{t}+\sum_{i} a_{C}^{i} p_{i}{ }^{t}+F C^{t}\left(Y_{C}{ }^{t-1}\right)\right] y_{C}{ }^{t}
$$

これに伴い, 低公害車の本体価格も以下のようになる.

$$
p_{C}=a_{C}^{0} c_{C}{ }^{t}+\sum_{i} a_{C}^{i} p_{i}^{t}+F C^{t}\left(Y_{C}^{t-1}\right)
$$

これより, 低公害車産業が高公害車産業と同じ技術 を持つとすると, 初期時点では価格の中の固定部分 $F C^{t}$ により低公害車の価格の方が相対的に高くなり， その累積生産台数の増加とともに $F C^{t}$ が減少して, 高 公害車と低公害車の価格差が縮まっていく現象が表現 でる。これは，いわゆる低公害車製造産業における習 熟効果を表しているものである.

\section{5 家計の行動モテル}

家計は, 産業に生産要素を提供することにより所得 を得，それをもとに消費行動をとると同時に，次期の 資本ストックを増加させるために貯蓄および投資行動 もとるものとする.

\section{（A）消費行動モデルの概要}

家計の消費行動モデルは，図 2 のように階層的にモ デル化する.

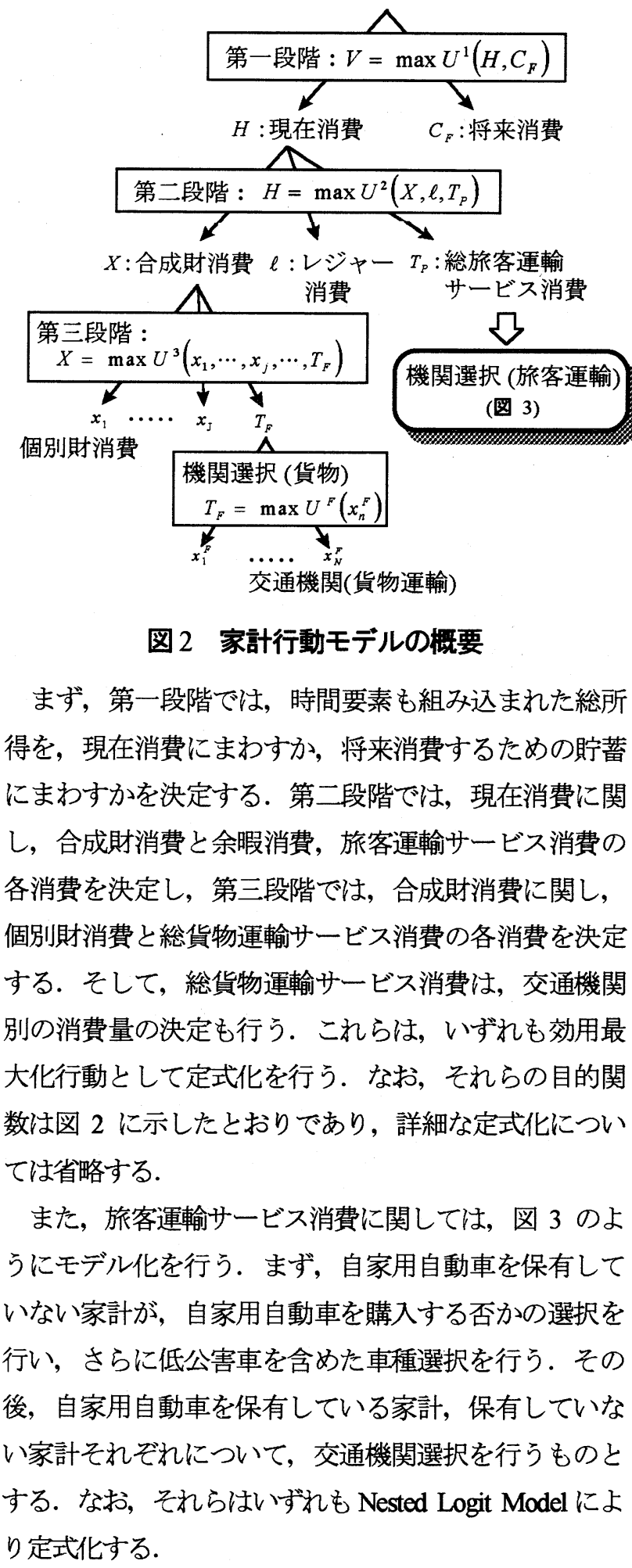




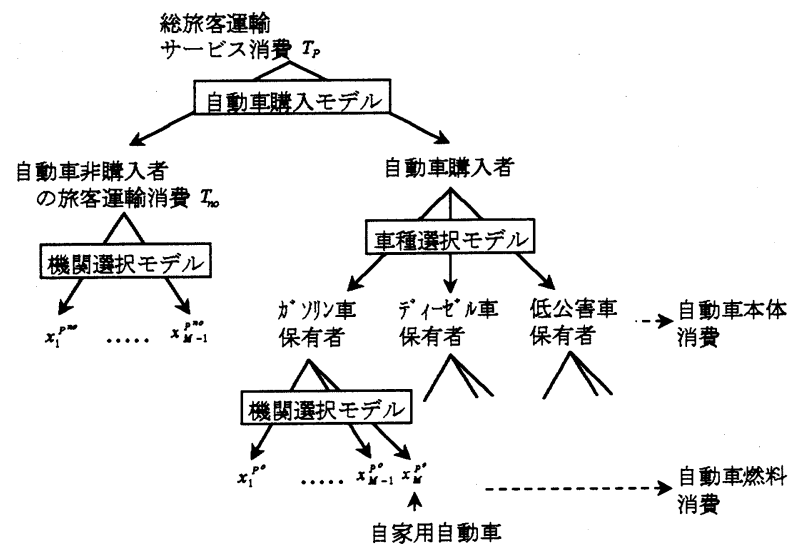

図 3 旅客運輸サービス消費行動モデル

ここで，家計の自家用自動車に関わる旅客運輸サ一 ビスについては，家計自らがそのサービスを生産して 自らが消費するものとし，そのサービスの生産には， 自動車本体と自動車燃料，そして時間資源が投入され るものとして定式化を行っている.

\section{（B）貯韾・投資行動モデル}

家計は，生産要素を提供することにより得られる所 得の中から, 次期の資本ストック蓄積の源泉となる貯 蓄も行うものとする．その貯蓄については，前項にお いて将来消費量が決定されることより求められる．家 計は，その貯蓄を投資する投資かとしての行動も行う ものとする．本モデルでは，資本として自動車資本を 別途導入したため，家計はより次期の収益が高い資本 へ投資を行うものとして定式化を行っている(図 4).

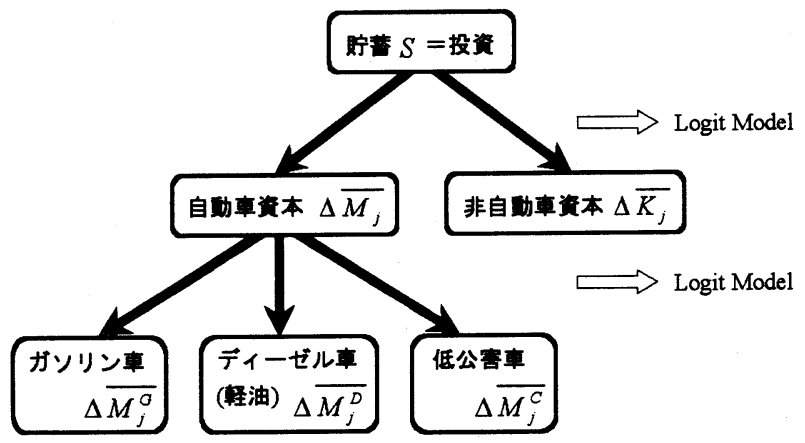

図 4 投資先選択行動

すなわち，各資本への投資選択確率を以下のような Nested Entropy モデルの枠組みで定式化を行ったの.

$$
\begin{aligned}
\max _{\Phi_{h}^{I}, P_{c}^{I}}\left[Z H^{I F}\left(\Phi_{h}^{I F}, P_{c}^{I}\right)\right. & +P_{K}^{I}\left\{-\frac{p_{S_{K}} p_{X}}{p_{K} \varphi_{K}}\right\} \\
& \left.-\frac{1}{\theta^{I}} \sum_{c}\left\{P_{c}^{I} \cdot \ln P_{c}^{I}\right\}\right]
\end{aligned}
$$

$$
\text { s.t. } \sum_{c} P_{c}^{A}=1, \sum_{h} \Phi_{h}^{I F}=P_{M}^{I}
$$

ここで,

$Z H^{I F}=\sum_{h} \Phi_{h}^{I F}\left\{-\frac{p_{S_{\mathbf{x}_{h}}} p_{X}}{p_{M^{n}} \varphi_{M^{h}}}\right\}-\frac{1}{\theta^{I F}} \sum_{h}\left\{\Phi_{h}^{I F} \cdot \ln \frac{\Phi_{h}^{I F}}{P_{M}^{I}}\right\}$

ただし, $P_{c}^{I}$ : 資本 $c(=M:$ 自動車資本, $=K:$ 非自 動車資本)への投資確率， $p_{S_{\mathrm{K}}}$ : 非自動車資本の資本財 購入価格, $p_{X}$ : 合成財価格, $p_{K}$ : 非自動車資本価格, $\varphi_{K}$ : 資本のフロー・ストック比率, $\Phi_{h}^{I F}:=P_{M}^{I} \cdot P_{h}^{I F}$, $P_{h}^{I F}$ : 燃料種別 $h$ の白動車資木几の投資確率, $\theta^{I}, \theta^{F}$ : ロジットパラメータ.

これを解くと，以下のように各選択確率が得られる.

【資本 $c$ への投資確率】

$P_{M}^{I}=$

$\overline{1+\exp \theta^{I}\left[\left\{-\frac{p_{S_{K}} p_{X}}{p_{K} \varphi_{K}}\right\}-\frac{1}{\theta^{I F}} \ln \sum_{h} \exp \left\{\theta^{I F}\left(-\frac{p_{S_{U_{h}}} p_{X}}{p_{M^{n}} \varphi_{M^{n}}}\right)\right\}\right]}$

【燃料種別 $h$ の自動車資本への投資確率】

$$
P_{h}^{I F}=\frac{\exp \left\{\theta^{I F}\left(-\frac{p_{S_{M h}} p_{X}}{p_{M^{n}} \varphi_{M^{n}}}\right)\right\}}{\sum_{h} \exp \left\{\theta^{I F}\left(-\frac{p_{S_{M h}} p_{X}}{p_{M^{n}} \varphi_{M^{n}}}\right)\right\}}
$$

\section{6 市場均衡条件式}

本モデルにおける市場均衡条件を示す.

財市場 : $\mathbf{y}=[\mathbf{I}-\mathbf{A}]^{-1} \mathbf{x}$

労働市場 : $L_{S}(q)=\sum_{j} L_{j}$

然料種別 $h$ の自動車資本：

$$
\overline{M^{h}}=\sum_{j} \mathrm{P}_{h}^{F} M_{j}
$$

非自動車資本市場 : $\bar{K}=\sum_{j} K_{j}$

産出財価格：

$$
\left[\begin{array}{c}
p_{1} \\
\cdot \\
\cdot \\
p_{j} \\
\cdot \\
\cdot \\
p_{J}
\end{array}\right]^{\prime}=\left[\begin{array}{c}
a_{1}^{0}\left\{p_{L} D_{L_{1}}+p_{M} D_{M_{1}}+p_{K} D_{K_{1}}\right\} \\
\cdot \\
\cdot \\
a_{j}^{0}\left\{p_{L} D_{L_{J}}+p_{M} D_{M_{J}}+p_{K} D_{K_{J}}\right\} \\
\cdot \\
\cdot \\
a_{J}^{0}\left\{p_{L} D_{L_{J}}+p_{M} D_{M_{J}}+p_{K} D_{K_{J}}\right\}
\end{array}\right]^{\prime}[\mathbf{I}-\mathbf{A}]^{-1}
$$

最後の式は，式(7)を行列にて表現したものである. 


\section{3. 便益の定義}

本研究では, 等価的偏差 EV の概念を用いて便益を 定義する. すなわち, 各期ごとにEVを導出し, 現在価 值換算して総和をとり総便益を求めることにする.こ のとき，各期ごとのEVは，貯蓄分を控除した現在消費 の水準に基づいて定義される必要がある. よって, 図 2 の第二段階にて導出される現在消費の水準 $H^{*}\left(q^{t}, I_{D}^{2 t}\right)$

に基づき便益を定義するク。

$$
H^{*}\left(q^{t A}, I_{D}^{2 t A}+E V^{t}, r^{t A}\right)=H^{* t B}
$$

ただし, $q$ : 産出財価格ベクトル, $I_{D}^{2}$ : 貯蓄分を控除 した総所得.

また, 純便益 $S N B$ は, 式(16)を現在価値で割り引い て総和を取ることにより求める.

$$
S N B=\sum_{t=0} \frac{E V_{t}}{(1+i)^{t}}
$$

ただし, $i$ : 社会的割引率.

\section{4. 政策シミュレーション}

\section{1 低公害車製造産莱の費用曲線}

シミュレーション分析を行うにあたり，低公害車製 造産業の費用曲線を推定する必要がある。ここでは, 過去の自動車本体価格と自動車生産台数との関係から 単位費用曲線の推定を行い，それをもとに低公害車の 単位費用曲線の推定を行った. その結果を図 5 に示す.

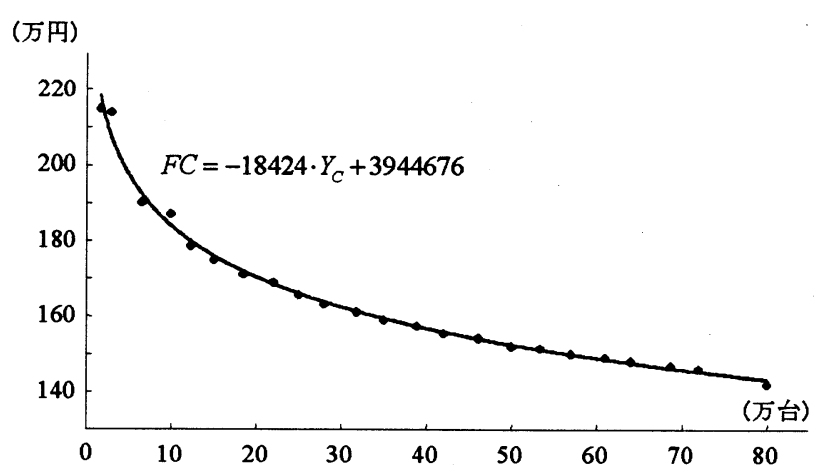

図 5 低公害車製造産業の費用関数

\section{2 シミュレーションの設定}

図 5 の低公害車製造産業の費用関数を, 第 2 章にて 構筑した DCGE モデルに導入して行ったシミュレーシ
ヨン分析の結果を示寸. ここでは, 以下のような 3 ケ ースについて数值計算を行った.

Casel）モデルへの低公害車の導入を行わなかった場合

Case2) モデルへの低公害車の導入を行い，その促進政 策は実施しない場合

Case3) 低公害車普及促進政策として, 補助金支給(25 万円/台)政策を実施した場合

Casel)は低公害車の導入が果たして本当に環境改善と いう点で有効であるのかを検討するために行ったもの である. Case2)は図 5 のような低公害車製造産業の費用 関数のもとでの低公害車の普及状況をシミュレーショ ンするためのものである. そして, 最後に Case3)にて 補助金政策が有効となりうるかの検討を行っている.

\section{3 シミュレーション結果}

4.2 節の設定のもと, 評価期間 20 年, 社会的割引率 $1.5 \%$ で行ったシミュレーションの結果を示す.

まず，低公害車の普及台数の推移を図 6 に示す.こ れによれば，Case2)では平均して年に約 3 万 5 千台，そ して補助金政策を行った Case3)では, 4 万台強の低公害 車が普及する結果となった。

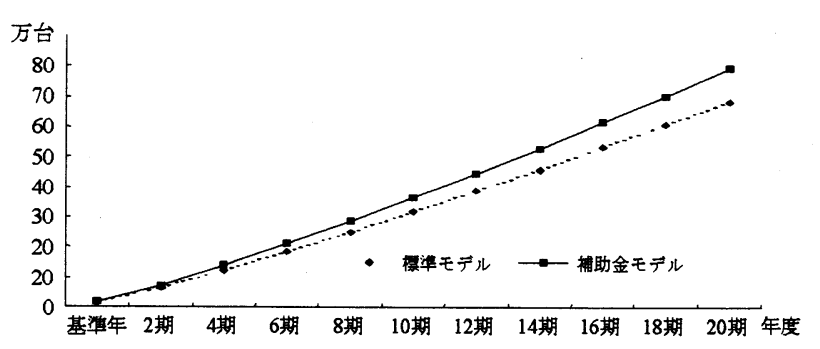

図 6 低公害車普及台数の推移

また，高公害車も加えた自動車総台数の推移を図 7 に示す。これによれば，低公害車の増加が影響して，6 期目以降 Case1)より Case2), 3)の方が総台数は増大する 結果となった.

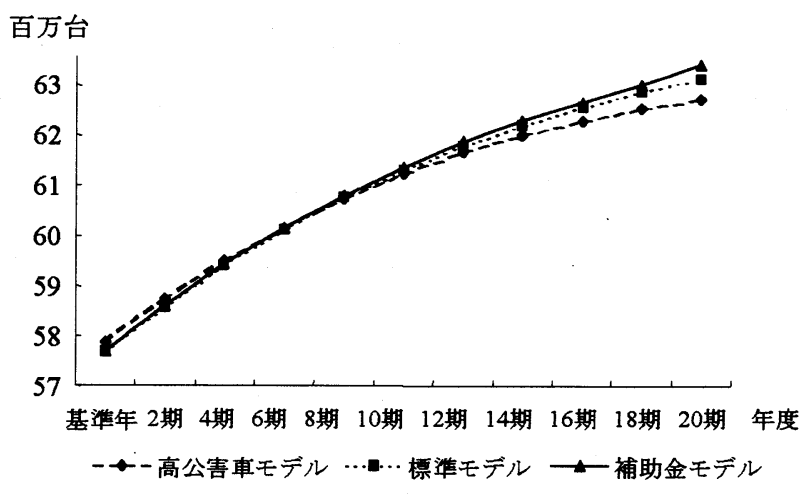

図 7 自動車総台数の普及推移 
図 6 の低公害車の普及台数推移を受けて, 外部不経 済削減便益を計測した結果を図 8 に示す. 補助金を支 給した Case3)では，かなり大きな外部不経済削減便益 が発生していることがわかる.

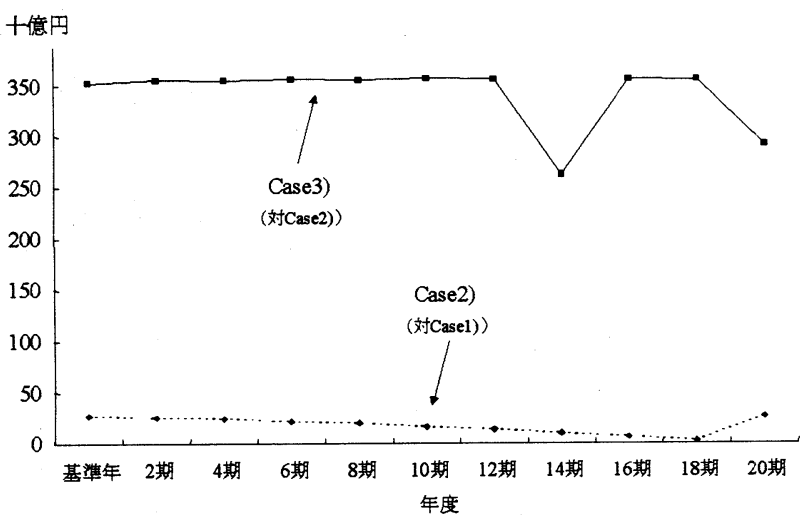

図 8 外部不経済削減便益の推移

その一方で, 高公害車より価格面で不利な低公害車 を普及させたことによる市場経済的不便益の計測を行 った(図 10). なお，補助金支給の政策では，補助金の 財源を家計の一括税て賄うものとしている.

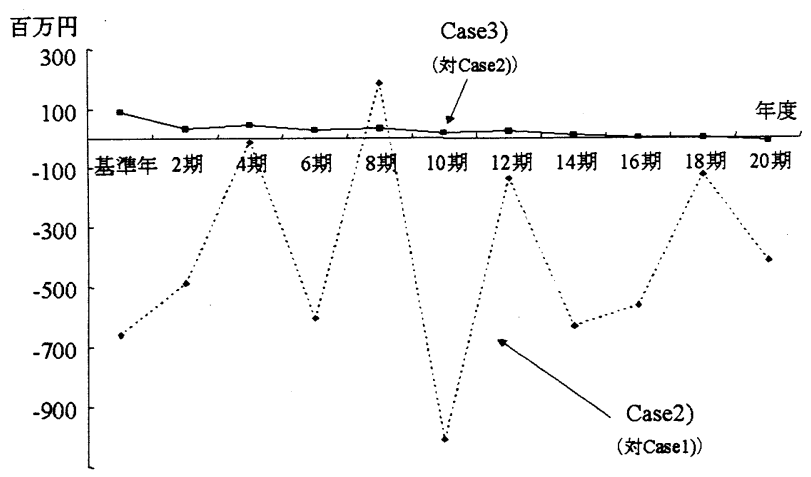

図 9 市場経済的不便益の推移

最後に，社会的割引率 $1.5 \%$ として，評価期間 20 年で の純便益の計測を行った. その結果を表 1 に示す.

表 1. 便益評価結果

\begin{tabular}{|c|c|c|}
\hline & $\begin{array}{c}\text { Case2) } \\
\text { (対 Case1) })\end{array}$ & $\begin{array}{c}\text { Case3) } \\
\text { (対 Case2) })\end{array}$ \\
\hline 市場経済的不便益 & -0.045 & 0.003 \\
\hline 外部不経済削減便益 & 1.935 & 3.756 \\
\hline 社会的純便益 & 1.683 & 3.219 \\
\hline
\end{tabular}

(兆円)

これより，Case2)，Case3)ともに，正の純便益を生む 結果となった。 これは，市場経済的不便益より外部不 経済削減便益の方がかなり大きな便益を生んでいるこ とが原因と考えられる.

\section{5. 結論}

本研究では，近年深刻な問題となっている自動車交 通に起因する外部不経済の削減に対して有効となりう ると考えられている低公害車の導入について，国民経 済レベルでの評価を行った．具体的には，動学的応用 一般均衡分析の枠組みに，低公害車製造産業の習熟効 果を組み入れた経済モデルの開発を行い，低公害車の 普及予測とともに外部不経済の削減便益についても同 時に計測を行いうる点を明らかにした。

その結果，まず低公害車の習熟効果に伴う低公害車 の増大は, 外部不経済の削減といった面で大きな効果 のあることがわかり，さらに低公害車の購入に際して 補助金を支給することにより社会的な純便益は，政策 無しの場合に比べて 2 倍近くの大きさとなることがわ かった.

今後の課題としては, 1. 然料税増徴策のような他の 政策との複合的な政策の中での補助金支給政策の評価, 2. 補助金支給政策において，毎期ごとに補助金支給額 を変更した場合のスケジューリング問題，などが挙げ られる。

\section{参考文献}

1) (財)運輸経済研究センター(1994)：環境と運輸・交 通, 運輸経済研究センター。

2）低公害車の長期普及計画策定調査委員会(1996)：低 公害車の長期普及計画策定調查報告書, 運輸省.

3）武藤慎一・上田孝行・森杉壽芳(1998)：自動車交通 による外部不経済抑制策の国民経済的評価，運輸政 策研究 No. 1, pp. 39-53.

4) Ginsburgh,V. and Keyzer,M (1997): The Structure of Applied General Equilibrium Models, The MIT Press, pp. 374-376.

5) 伊藤元重・清野一治・奥野正寛・鈴木興太郎(1988)： 産業政策の経済分析，東京大学出版会.

6) 宮城俊彦: ネスティッド・エントロピーモデルとそ の応用，土木計画学研究・講演集 No.18(2), pp.163166, 1995.

7) J.B.Shoven and J.Whalley:Applying General Equilibrium, Cambridge University Press.1992. (小平裕訳 : 応用一般 均衡分析一理論と実際，東洋経済新報社，1993. 